\title{
Efficient Catalysis of Ammonia Borane Dehydrogenation
}

Melanie C. Denney, Vincent Pons, Travis J. Hebden, D. Michael Heinekey* and Karen I. Goldberg*

Department of Chemistry, University of Washington, Box 351700, Seattle, Washington, 98195-1700.

\section{Experimental Details}

General Experimental..........................................................................................................

Synthesis of Complexes..................................................................................................................S3

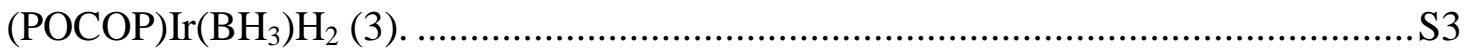

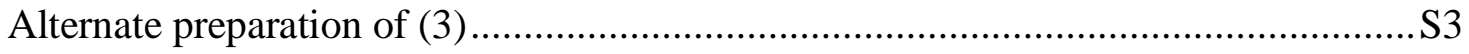

NMR Studies..................................................................................................................................S4

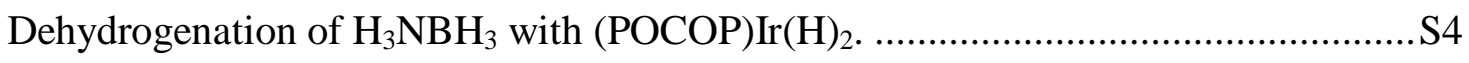

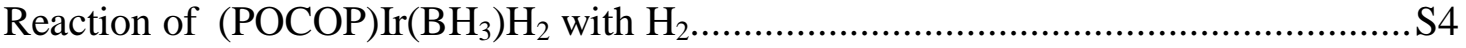

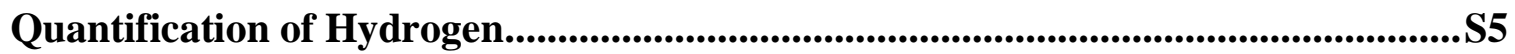

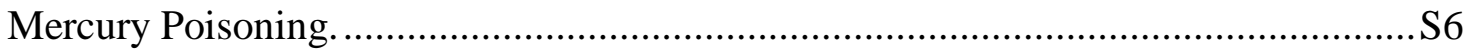

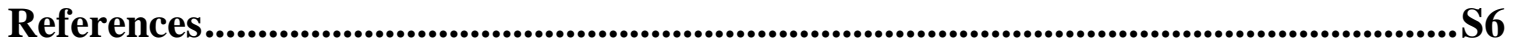




\section{General Experimental}

Unless otherwise stated, all manipulations were carried out using high vacuum techniques or under an atmosphere of argon in a glove box (Vacuum Atmospheres) or using Schlenk techniques. THF was purified by passage through a column of alumina, and pentane through columns of alumina and Q5 reactant. THF- $d_{8}$ was vacuum transferred from sodium metal/benzophenone. (POCOP) $\operatorname{Ir}(\mathrm{H})_{2}$ and (POCOP) $\operatorname{IrHCl}$ were prepared as described in the literature $(1,2)$. Ammonia borane was sublimed at $65^{\circ} \mathrm{C}$ under vacuum before use (3) and stored at $-35^{\circ} \mathrm{C}$ in a glove box. All other reagents were used as received.

Solution NMR spectra were collected at room temperature using Bruker AV300, DPX200 and DRX499 spectrometers. ${ }^{1} \mathrm{H},{ }^{2} \mathrm{H}$ and ${ }^{13} \mathrm{C}\left\{{ }^{1} \mathrm{H}\right\}$ NMR spectra were referenced to residual solvent signals and shifts are reported in parts per million (ppm) downfield of tetramethylsilane. ${ }^{31} \mathrm{P}\left\{{ }^{1} \mathrm{H}\right\}$ NMR spectra were referenced to an external $\mathrm{H}_{3} \mathrm{PO}_{4}$ sample set to $0 \mathrm{ppm}$ and ${ }^{11} \mathrm{~B} \mathrm{NMR}$ spectra to an external sample of $\mathrm{BF}_{3} \cdot \mathrm{Et}_{2} \mathrm{O}$ set to $0 \mathrm{ppm}$. Solid state ${ }^{11} \mathrm{~B}\left\{{ }^{1} \mathrm{H}\right\}$ NMR spectra were performed at room temperature on a Varian $300 \mathrm{~S} \mathrm{MHz}$ spectrometer. The solid sample was spun at $9.7 \mathrm{kHz}$, using $5 \mathrm{~mm}$ silicon nitride rotors filled in a glove box under an atmosphere of dry nitrogen. Infrared spectra were recorded on a Bruker Optics Tensor27 FT-IR spectrometer at room temperature.

Safety Note. Extreme caution should be used when carrying out these reactions as the release of hydrogen can lead to sudden pressurization of reaction vessels. 


\section{Synthesis of Complexes}

(POCOP) $\operatorname{Ir}\left(\mathbf{B H}_{3}\right) \mathbf{H}_{2}$ (3). A $1.0 \mathrm{M}$ solution of borane-tetrahydrofuran complex in THF $(0.5 \mathrm{~mL}, 0.5 \mathrm{mmol})$ was added to a solution of $\operatorname{Ir}(\mathrm{H})_{2}(\mathrm{POCOP})(0.0573 \mathrm{~g}, 96.8$ $\mu \mathrm{mol})$ in THF (3 mL). An immediate color change from red to yellow was observed. The solution was stirred at room temperature for 10 mins and the volatiles removed in vacuo to leave a yellow solid. Complex $\mathbf{3}$ was found to be stable in a nitrogen atmosphere, but decomposed slowly on exposure to air. Yield: $0.0498 \mathrm{~g}(85 \%)$. Crystals suitable for X-ray diffraction were grown by the slow evaporation of a THF solution of $\mathbf{3}$. ${ }^{1} \mathrm{H}$ NMR $\left(\mathrm{THF}-d_{8}, 300 \mathrm{MHz}\right) \delta 7.0\left(\mathrm{br}, 2 \mathrm{H}, \mathrm{B} H_{2}\right) 6.71\left(\mathrm{t}, 1 \mathrm{H},{ }^{3} J=8.0 \mathrm{~Hz}, \mathrm{H} 4\right) ; 6.42(\mathrm{~d}$, $2 \mathrm{H},{ }^{3} J=7.8 \mathrm{~Hz}, \mathrm{H} 3,5$ ); 1.46 (virtual triplet, $18 \mathrm{H}$, apparent $J=7.0 \mathrm{~Hz},{ }^{t} \mathrm{Bu}$ ); 1.36 (virtual triplet, $18 \mathrm{H}$, apparent $\left.J=7.4 \mathrm{~Hz},{ }^{t} \mathrm{Bu}\right) ;-5.4(\mathrm{~s} \mathrm{br}, 1 \mathrm{H}, \mathrm{BH}) ;-6.6(\mathrm{~s} \mathrm{br}, 1 \mathrm{H}, \mathrm{BH}) ;-20.64(\mathrm{t}$, $1 \mathrm{H}, J=12.5 \mathrm{~Hz}, \mathrm{Ir}-H) .{ }^{31} \mathrm{P}\left\{{ }^{1} \mathrm{H}\right\} \mathrm{NMR}\left(\mathrm{THF}-d_{8}, 96 \mathrm{MHz}\right) \delta 171.3$ (s). ${ }^{13} \mathrm{C}$ NMR (THF$\left.d_{8}, 50 \mathrm{MHz}\right) \delta 165.0\left(C_{\mathrm{q}}\right.$, vt, apparent $\left.J=5.3 \mathrm{~Hz}, \mathrm{C} 2,6\right), 125.1(C \mathrm{H}, \mathrm{C} 4), 105.1(C \mathrm{H}, \mathrm{vt}$, apparent $J=5.54 \mathrm{~Hz}, \mathrm{C} 3,5), 41.14$ and $40.34\left(C_{\mathrm{q}}\right.$, vt, apparent $J=12.4$ and $12.6 \mathrm{~Hz}, 2 \mathrm{x}$ $\left.\mathrm{P}^{t} \mathrm{Bu}_{2}\right), 28.98$ and $28.47\left(C \mathrm{H}_{3}\right.$, vt, apparent $J=3.02$ and $\left.2.44 \mathrm{~Hz}, 2 \times \mathrm{P}^{t} \mathrm{Bu}_{2}\right) .{ }^{11} \mathrm{~B} \mathrm{NMR}$ $\left(\mathrm{THF}-d_{8}, 160 \mathrm{MHz}\right) \delta 13.6\left(\mathrm{~s}\right.$ br). IR $\left(\mathrm{KBr}, \mathrm{cm}^{-1}\right) 2466,2441,2285,2219\left(v_{\mathrm{B}-\mathrm{H}}\right), 1930$ $\left(v_{\text {Ir-H }}\right)$.

Alternate preparation of (3). A slurry of $\mathrm{NaBH}_{4}(0.137 \mathrm{~g}, 3.62 \mu \mathrm{mol})$ in THF $(15 \mathrm{~mL})$ was added to a solution of (POCOP) $\mathrm{IrHCl}(0.169 \mathrm{~g}, 0.270 \mu \mathrm{mol})$ in THF (10 $\mathrm{mL}$ ). The dark red mixture was heated to $70{ }^{\circ} \mathrm{C}$ with vigorous stirring for 2 days. The resulting yellow-brown solution was filtered through Celite, and volatiles were removed in vacuo to give a yellow solid. Yield: $0.122 \mathrm{~g}(75 \%)$. 


\section{NMR Studies}

Dehydrogenation of $\mathrm{H}_{3} \mathrm{NBH}_{3}$ with $(\mathrm{POCOP}) \operatorname{Ir}(\mathrm{H})_{2}$. In a typical experiment, ammonia borane $(0.0026 \mathrm{~g}, 84 \mu \mathrm{mol})$ and $3(0.0020 \mathrm{~g}, 3.4 \mu \mathrm{mol}, 4.0 \mathrm{~mol} \%)$ were weighed into a J. Young NMR sample tube. THF- $d_{8}$ was added by vacuum transfer. Vigorous evolution of hydrogen gas and precipitation of a white solid was observed immediately upon commencement of thawing. The reaction was monitored by ${ }^{1} \mathrm{H}$ and ${ }^{31} \mathrm{P}\left\{{ }^{1} \mathrm{H}\right\}$ NMR spectroscopy. At the completion of the reaction more ammonia borane $(0.0028 \mathrm{~g}, 91 \mu \mathrm{mol})$ was added. Vigorous bubbling was observed again and the reaction was monitored by ${ }^{1} \mathrm{H}$ and ${ }^{31} \mathrm{P}\left\{{ }^{1} \mathrm{H}\right\}$ NMR spectroscopy.

Reaction of 3 with $\mathbf{H}_{2}$. A THF- $d_{8}$ solution of $3(0.0030 \mathrm{~g}, 4.9 \mu \mathrm{mol})$ in a $\mathrm{J}$. Young tube was degassed (three freeze-pump-thaw cycles) and then pressurized with hydrogen gas (1 or 5 atm.) The reaction was monitored by ${ }^{1} \mathrm{H},{ }^{11} \mathrm{~B}$ and ${ }^{31} \mathrm{P}\left\{{ }^{1} \mathrm{H}\right\} \mathrm{NMR}$ spectroscopy (Fig. S1). 


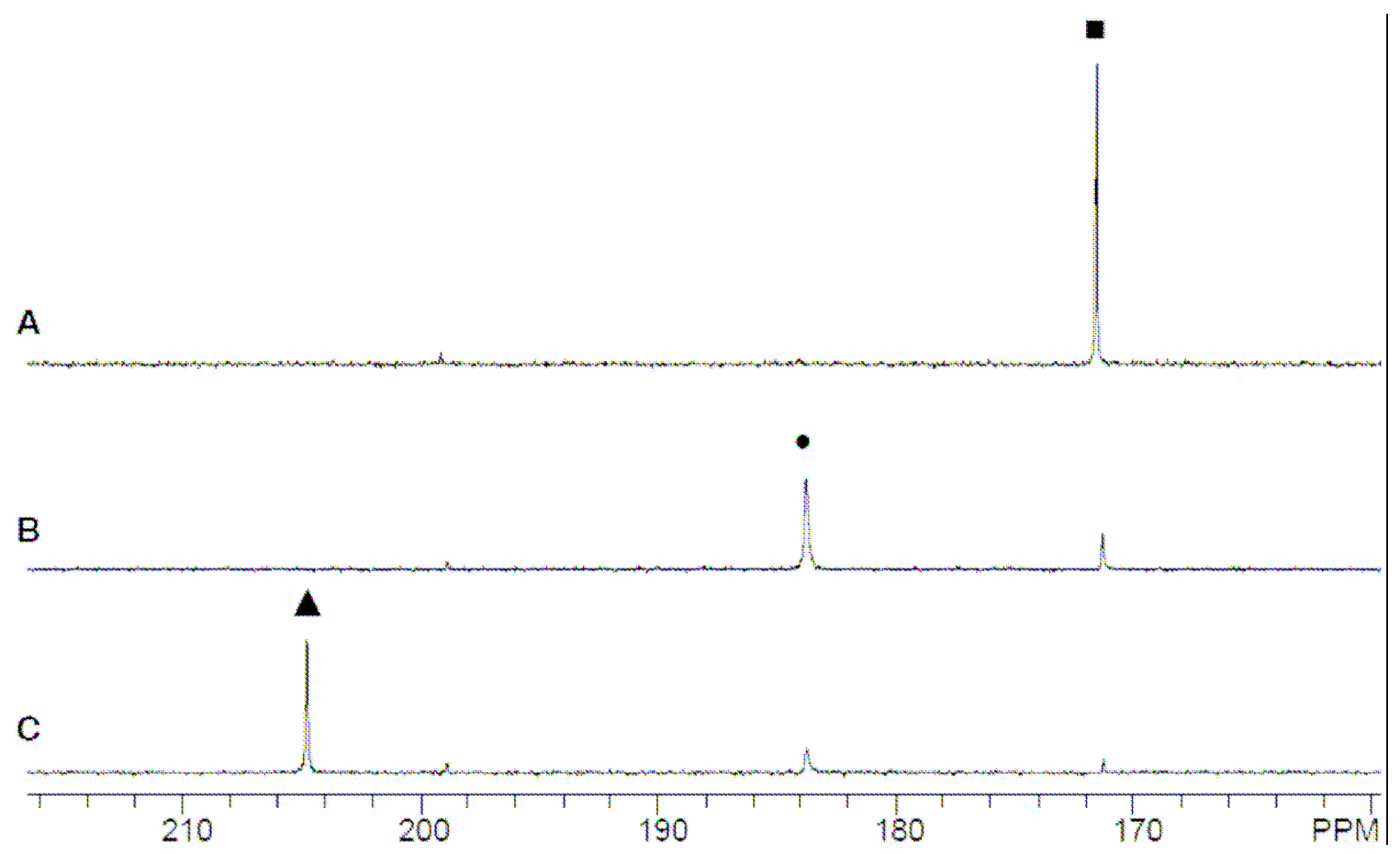

Fig. S1. Room temperature ${ }^{31} \mathrm{P}\left\{{ }^{1} \mathrm{H}\right\}$ NMR $\left(\mathrm{THF}-\mathrm{d}_{8}, 202 \mathrm{MHz}\right.$ ) (studies of the reaction of $\mathbf{3}$ with 5 atm $\mathrm{H}_{2}(\boldsymbol{\square}=\mathbf{3}, \bullet=\mathbf{2}, \boldsymbol{\Delta}=\mathbf{1})$. (A) Before $\mathrm{H}_{2}$ addition. (B) Four hours after addition of $\mathrm{H}_{2}$. (C) After degassing.

\section{Quantification of Hydrogen}

In a typical experiment, ammonia borane $(0.0425 \mathrm{~g}, 1.38 \mathrm{mmol})$ was dissolved in THF $(2.2 \mathrm{ml})$ in a $10 \mathrm{~mL}$ round bottom flask and the flask stoppered with a tight-fitting rubber septum. The required amount of a $8.4 \mathrm{mM}$ solution 1 in $\mathrm{THF}(0.81 \mathrm{~mL}, 0.5$ mol\%) was transferred via syringe to the stirred ammonia borane solution. Timing was started when the catalyst was injected into the ammonia borane solution. Immediate, vigorous gas evolution was observed along with the precipitation of a white solid. The hydrogen gas was collected in a water-filled, upturned burette through a needle connected to a thin Teflon tube. The volume of hydrogen gas collected was recorded periodically until the reaction was complete (Table S1). The procedure was repeated using 0.25 and $1.0 \mathrm{~mol} \%$ of catalyst. 
Table S1. Equivalents of hydrogen collected compared with the original amount of ammonia borane.

\begin{tabular}{cccc}
\hline $\begin{array}{c}\text { Catalyst Loading } \\
(\mathbf{m o l} \%)\end{array}$ & $\begin{array}{c}\text { Hg added } \\
(\mathbf{m o l} \%)\end{array}$ & $\begin{array}{c}\text { Equiv. } \mathbf{H}_{2} \\
\text { Collected }\end{array}$ & $\begin{array}{c}\text { Time } \\
(\mathbf{m i n s})\end{array}$ \\
\hline 1.0 & - & $1.01(3)$ & $3.2(8)$ \\
0.5 & - & $1.04(2)$ & $12.7(9)$ \\
0.5 & 94 & 1.01 & 14 \\
0.25 & - & $1.03(1)$ & $36(2)$ \\
\hline
\end{tabular}

At the end of the reaction, the solid was collected by filtration, rinsed with THF and dried in vacuo. ${ }^{11} \mathrm{~B}\left\{{ }^{1} \mathrm{H}\right\} \mathrm{NMR}\left(96 \mathrm{MHz}\right.$, solid) $\delta-18$ ppm. IR (KBr disk, $\left.\mathrm{cm}^{-1}\right) 3302$ (s), 3249 (s), 2393 (s br), 2315 (s br), 1559 (s sh), 1400 (w), 1208 (s br), 1082 (m), 1057 (m), 948 (w), 841 (m), 655 (w).

Mercury Poisoning. The experiment was carried out as described above, but mercury metal $(0.26 \mathrm{~g}, 1.3 \mathrm{mmol})$ was added to the ammonia borane solution and stirred vigorously before addition of the catalyst.

\section{References}

1. Göttker-Schnetmann, I.; White, P. S.; Brookhart, M., Organometallics 2004, 23, 1766.

2. Göttker-Schnetmann, I.; White, P.; Brookhart, M. J. Am. Chem. Soc. 2004, 126, 1804.

3. Wang, J. S.; Geanangel, R. A. Inorg. Chim. Acta 1988, 148, 185. 